\title{
АЖ ҮЙЛДВЭРЖИЛТ БОЛОН ТАЛ НУТГИЙН УСНЫ ЭХ СУРВАЛЖ ДУТАГДАХ НӨХЦӨЛ БАЙДАЛ ХИЙГЭЭД ТУУНИЙ YР ДАГАВАР 1
}

\section{М. БУрэнжсаргал}

Тус өгүүлэлд аж үйлдвэржилтийн явцад Өвөр Монгольын хөдөө нутагт уул уурхай нээж ашиглах, хот балгас тэлж хөгжүүлсэний дүнд богино хугащаанд эдийн засгийн хурдан өсөлт бий болсон ч тал нутгийн усны эх сурвалж дутагдалтай нөхиөл байдлаас шалтгаалж экологийн тэнцвэргүй байдал Үүссэн зэрэг сөрөг үр дагавар авчирсаныг зарим жишээ баримтаар нотлон өгҮүлсэн болно. Монгольгн өндөрлөгийн бэлчээрийн мал аж ахуй бол монгол нүүдэл, урт удаан түүхэн иза хугацааны явиад байгалийн хатуу шалгалт, хүний нийгмийн хувьсал иилжсилтийн сорилтоор дамжин нотлогдсон нэгэн төрлийн сонгодог эдийн засгийн хэлбэр болно.

Түлхиүр үг: Аж үйлдвэржилт, усны эх сурвалж, Монголын өндөрлөг, бэлчээрийн мал аж ахуй

\section{Нэг. Аж үйлдвэржилтэд усны эх сурвалж шаардагдах нь}

\section{1. Аэс үйлдвэр, уул уурхай ашиглах болон усны эх сурвалэнийн шаардлага}

Уул уурхай, аж үйлдвэр хөгжүүлэхэд хэрэглэх усны эх сурвалжийн шаардлага дараах хэдэн зүйлээс урган гарч ирдэг.

ЭнэхүҮ өгүүллийг БНХАУ-ын ӨМӨЗО-ны залуучуудын шинжлэх ухааны сангийн 2016 оны төслийн (内蒙古自治区2016年度 “草原英才” 工程青年创新人才培养 计划专项基金) хүрээнд бичив. 
Аж үйлдвэржилт болон тал нутгийн усны эх сурвалж дутагдах нөхцөл байдал хийгээд түүний үр дагавар

Хамгийн түрүүнд уул уурхайг нээж ашиглах хөдөлгөгч хүчний нөхцөл байдлаас болдог байна. Өвөр Монгол орны уурхайн баялгийг нээж ашиглахад ерөнхийдөө цахилгаан эрчим хүчийг ихээр хэрэглэдэг бөгөөд тэрхүу цахилгаан эрчим хүчийг гаргаж авахад нэг талаар их хэмжээний усны эх баялгийг ашигладаг байна. Энэ нь нөгөө талдаа их хэмжээний бохирдсон усыг ойр орчмын гол мөрөн, нуур цөөрөм болон газар доорх далд усан давхаргыг бохирдуулдаг байна. Зарим судлаачдын бичсэнээр Өвөр Монголд тэгшитгэсэн нэг тонн нүүрсийг малтахад хоёр тонн бохир ус бий болгож гаргадаг байна. Тухайлбал, нүүрс болон төмрийн хүдрийг олборлон гаргасны дараа цэвэрлэхэд ус их хэмжээгээр хэрэглэнэ. Нүүрсийг мөн адил уурхайгаас малтаж гаргасны хойно их хэмжээний усаар цэвэрлэж угаадаг. Нүүрсийг угаах явцад тухайн газрын усны эх сурвалжийг ашиглах эрэлт хэрэгцээ ихэсч ба уурхай ихээр нээгдэхийг дагалдан усны эрэлт ч тасралтгүй нэмэгддэг. Өөрийн өртөг болон технологийн одоогийн нөхцөл байдлаас шалтгаалан энэхүү усны эрэлтийг тухайн газарт бусад орноос татан авч орлуулж шийдвэрлэх боломж байхгүй байна. Дээрх усны эх сурвалжийн эрэлтээс гадна бас тухайн газар оронд байгаа уул уурхайн ажилчдыг ундны болон ахуйн хэрэглээний усаар хангах хэрэгтэй болно. Эдгээр хүн амын усны хэрэгцээ нь уул уурхайн үйлдвэржилтийн нөхцөл байдлаас бий болсон зүйл юм. Тиймээс түүнийг аж үйлдвэр, уул уурхай ашиглахад хэрэглэх усны эх сурвалжийн шаардлагын хэмжээнд оруулж үзэх хэрэгтэй.

Уул уурхайн баялаг ихтэй Өвөр Монгол орноор авч үзэхэд: Үйлдвэр, уул уурхайн том том төслүүдийг хэрэгжүүлэх явцад тухайн орны усны эх сурвалжийн нийлүүлэлтийн нөхцөл байдалд туйлын ноцтой сорилт учирсан байдаг. Эдгээр уул уурхайн эрдэс баялаг төвлөрсөн орон нутагт ган хуурайшилт ихтэй буюу хагас ган хуурайшилт бүхий цаг агаарын хүнд нөхцөл байдал хөдөө оронд нутагт бүрхэж байна. Тус орон нутгийн усны эх сурвалж туйлын дутагдалтай бөгөөд ус, шороон алдагдал, хөрс шорооны эвдрэл хүнд ноцтой болж, ургамлын мөөгөнцөр, экологийн орчин тун хуурайшиж байна. Аж үйлдвэржилтээс болж газар дорхи усны түвшин доошилж, их хэмжээний газрын давхарга хуурайшсан ба далд усны ситемийн тэнцвэр эвдэгдсэний улмаар усны эх баялаг хомсдож, худгийн ус ширгэж, тухайн газрын хүмүүсийн амьдралд хэрэглэх ундны ус, 
аж үйлдвэр, мал аж ахуй ба газар тариаланд хэрэглэх усны нөөцөд нөлөөлсөн байна.

\section{2. Хот суурин газрын тэлэлт болон усны эх баялгийн эрэлт шиардлага}

Аж үйлдвэржилтийн нэг чухал агуулга бол хотжилтын явц юм. Хот балгасны хэрэглэх усны ерөнхий хэмжээ тасралтгүй нэмэгдэж, хот суурин газар тэлэх тусам аж үйлдвэрийн бүтэц өөрчлөгдөн, үйлдвэр болон хотын бүтээн байгуулалт нэмэгдсэнээр хот суурины хэрэглэх усны хэмжээ болон усны хэрэглээний бүтцэд гүн гүнзгий хувиралт гардаг. Хот балгас хөгжих явцад хотын орчин тойрон болон дүүргийн хэрэглээний усны байдалд ч өөрчлөлт гардаг. Үүний зэрэгцээ хот балгасын ойр орчны хэрэглээний усны чанар, ерөнхий хэмжээ нь эргээд хот балгасны доторх хэрэглээний усанд нөлөөлдөг. Онцгойлон усны эх сурвалж дутмаг газар оронд хотжилтын явцад тодорхой хягаарлалтад ордог байна. Жишээлбэл, Хятадын умард орон хийгээд зарим далайн дагуух бүсэд усны бохирдол нь усны хэрэглээнд шууд нөлөөлсөнөөс болж усны эх сурвалжийн нөхцөл шалтгаан нь хотжилтын явцыг удаашруулах болсон байна. Хот суурин тэлж байгаа нь хүн ам нэмэгдэж байгааг харуулдаг. Хотын хүн амын өсөлтийг дагалдан эд баялаг хийгээд хөрөнгө хогшил хот руу тасралтгүй бөөгнөрч, үйлдвэрлэл амьдрал өргөжихийн хэрээр хотын ус авах, ус хэрэглэх төвлөрсөн байдалтай болдог байна.

Хотжилтын түвшин болон усны эх баялгийн ашиглалтын хэмжээтэй адил харилцаагаар хувирах хандлагатай байдаг. Хотжилтын түвшин өндөр болох тусам хотын төхөөрөмж хийгээд суугуул иргэдийн усны эх баялгийн эрэлтийн хэмжээ улам их болно. Өвөр Монголын байгаль орчин ерөнхийдөө гантай байдгаас шалтгаалан орон бүсийн усны эх баялгийн нөхцөл байдал өдөр ирэх тусам өсөн нэмэгдэж байгаa хотын их хэмжээний усны эрэлт шаардлагыг хангах боломжгүй байдалд орж байна. 2010 оны тоо бүртгэлийг үндэслэбэл, Хөххот, Бугат, Ордос зэрэг гурван хотын нэг хүнд оногдох ус хангалтын (нийлүүлэлтийн) хэмжээ тус бүр 78.93 тонн, 91.74 тонн, 34.40 тоннд байгаа нь Хятад улсын дундаж хэмжээ болох 133.10 тонноос бүр доор байдалд байв. Хөххот ба Ордос хот 
Аж үйлдвэржилт болон тал нутгийн усны эх сурвалж дутагдах нөхцөл байдал хийгээд түүний үр дагавар

нь Өвөр Монголын дундаж хэмжээ болох 85.17 тонны түвшнээс ч бас доор хэмжээнд оржээ. ${ }^{2}$ Үүнээс бид усны эх баялгийн эрэлт нийлүүлэлтийн тэнцвэргүй байдал нь Өвөр Монгол орны нийгэм болон эдийн засгийн хөгжилтэд хязгаарлах нөхцөл шалтгаан болж эхэлсэн гэдгийг мэдэж болно.

\section{Хоёр. Өвөр Монголын хөдөө дэх усны нөөцийн нөхцөл байдал}

Хятад улс бол газар тариалангийн том орон юм. Хятадын умард оронд мал аж ахуй хөжүүлдэг чухал муж, өөртөө засах орнууд, усны нөөцөд тулгуурласан газар тариалан, мал аж ахуй хөгжүүлэх бааз суурь байж, хүн амын хүнсний аюулгүй байдлыг хангах стратегийн чухал түшиц газар юм. Одоогийн байдлаар Хятадын усны нөөцийн хуримтлалын асуудал нэгэнт маргаангүй үнэн болсон байна. Усны эх сурвалж туйлын их дутагдаж эхэлсэн байдал доор, тариалангийн ус ашиглалтын бүдүүлэг хөгжлийн загвар хийгээд хоцрогдмол механикжилтын арга хэлбэрийг Өвөр Монгол орон, жич цаашлаад бүх хятад улсын ардын аж ахуй тогтвортой хөгжилд муугаар нөлөөлөх чухал асуудал болжээ. Өвөр Монголын хөдөө нутаг бол усны эх сурвалжаар ядмагийн дээрээс усны нөөцийн “механик хомсдол"-ын илрэл маш ноцтой болжээ. ${ }^{3}$ Хүмүүс энэ тухай зөвхөн онолын дөхөм шүүмжлэл хийх нь олонтаа боловч харин бодит ус ашиглалтын инженерийн болон технологийн арга хэмжээг авч хэрэгжүүлэх талаар дутмаг байна.

Бэлчээрийн мал аж ахуй бол Өвөр Монголын хөдөө орны эдийн засгийн гол хэлбэр байж, малчдын амьжиргааны гол тулгуур болдог. Мал аж ахуйд зориулсан усны хэрэглээ бүхэлдээ усны нөөцийн хувиаралтын дунд чухал байр эзэлнэ. Хүн амын огцом өсөлт хийгээд аж үйлдвэржилтийн түргэн явц, хөдөө орон дахь усны эрэлт нийлүүлэлтийн зөрчил өдөр ирэх тутам чангарсан байна. Өвөр Монголын их хэмжээний бэлчээр нутагт газар тариалан

2 Зэн Жянхун /甄江红/ “Өвөр Монголын Хөххот, Бугат, Ордос хотын аж үйлдвэржилт болон экологийн хамгаалалтын судалгаа” /内蒙古呼包鄂地区工业化与生态文明建 设研究/, [M], Хятадын Хөдөө Аж Ахуйн Хэвлэлийн Хороо, 2015.

3 Сун Цайжи /孙才志/ "Усны ядуулаг байдал доорх Хятадын хөдөө дэх усны нөөцийг нэмэгдүүлэхэд туслалцаа үзүүлэх бодлогын тухай судалгаa” / 水贫困背景 下中国农村水资源援助战略研究/ [J], Усны ашиглалтын эдийн засаг, 2015 (33) 
эрхэлдэг болсон ба худгийн усаар усалдгийн уршгаар бас газар доорх усны түвшин тасралтгүй доошилжээ. Нөгөө талаар үр тариалангийн ургацын алдалтыг багасгах зорилгоор урт хугацааны турш их хэмжээний химийн бордоо хэрэглэсэн, тариалангийн эм хийснээс хөрс шороонд бохирдол үлдээж, усны бохирдол гол горхи, нуур цөөрмийг бохирдуулж, мөн газар доорх усны системд ч нөлөөлжээ. Аж үйлдвэр, хот балгас, тариалангаас гарсан бохир ус, амьдралын хог новш, хүн амьтны ялгадас гэх мэтийн зүйлс гол усыг бохирдуулсан ба бүх бөмбөрцөгийн чанартай цаг агаарын хувирал хийгээд бүс нутгийн чанартай ган гачигтай жилүүд олшрох, улмаар тухайн хөдөө орны малчдын ундны усны аюулгүй байдалд нөлөөлөх болов. Эдийн засгийн ашиг хөөцөлдөхийн нөлөө нь хөдөөгийн усны нөөц, уул уурхай, үйлдвэр ашиглах зэрэгт тусах болжээ. Аж үйлдвэржилтийн явцад аж үйлдвэр болон үйлчилгээний секторт усны нийлүүлэлт ихэсч, бэлчээр нутагт хуваарилах нь багасаад мал аж ахуйн хөгжилд нөлөөлөв.

\section{Гурав. Аж үйлдвэржилтийн явцад усны дутагдлаас ҮҮссэн шинэ асуудал}

Уул уурхайг нээж ашиглахаас болж экологи орчинд учруулах эвдрэлийн үр дагавар маш хүнд ноцтой байдаг. Уул уурхайн баялгийг нээж ашиглах гэдэг нь урт удаан хугацаанд газрын давхаргын ажиллагаанаас болж бүрэлдсэн үнэ өртөг бүхий байгалийн бүтээгдэхүүнийг гаргаж авах явдал мөн. ЭнэхүҮ үйл явцад бэлчээр нутгийн экологийн орчинд ноцтой эвдрэл учруулна. Хамгийн түрүүнд их хэмжээний бэлчээр нутгийг эзэлж дайрдаг. Ургамлын бүрхэц эвдэгдэн, хөрс шороо элсэрхэгжин тачирдана. Хөрс хөдөлж, шороо хийснэ. Зөөвөрлөх явцад бас их хэмжээний бэлчээр нутгийг эвдэлж сүйтгэдэг. Малтаж гаргасан хог шороо, бохир ус бэлчээр нутгийг сүйтгэнэ. Засгийн газрын бэлчээр орлуулалтыг нэмэгдүүлж, дэд бүтцийг сайжруулах нь уул уурхайн баялгийг нээж ашиглах тухай таатай нөхцөлийг бүрдүүлдэг. Уул уурхай нээж ашиглах нь тухайн орон бүсийн дотоодын нийт бүтээгдэхүүнийг нэмэгдүүлж, орон нутгийн эдийн засгийн түргэн хөгжлийг ханган биелүүлсэн боловч усны эх сурвалж дутмагаас болж тухайн орны ард иргэдийн 
Аж үйлдвэржилт болон тал нутгийн усны эх сурвалж дутагдах нөхцөл байдал хийгээд түүний үр дагавар

амьдрал, байгалийн ургамалын бүрхэвчид бүр муу нөлөө үзүүлдэг. Их хэмжээний уурхай, үйлдвэр, замын бүтээн байгуулалт зэрэг нь мөн бэлчээрийг эзэлж, мал аж ахуй эрхлэх орчныг муутгадаг байна. Эдгээр үр дагаврын тухай хэдэн жишээ дурдвал:

1. Өвер Монголд бэлчээр нутаг ихээр тачирдсан газар орны малчдыг хөдөөгөөс нүүлгэн шилжүүлэх бодлогыг хэрэгжүүлсэн бөгөөд түүнийг “экологийн нүүдэл -иргэний инженерчлэл” гэж нэрлэжээ. Баяннуур хотын Урадын хойт хошуунд 2000 оноос эхэлж тэрхүү бодлогыг хэрэгжүүлжээ. Тоо бүртгэлээс үзвэл, тус хошууны хотжилтыг биелүүлэх, экологийн нүүдэл-иргэний инженерчлэлийг хэрэгжүүлэх үүднээс 729 өрхийн 2588 хүнийг хөдөөнөөс нүүлгэсэн нь тус хошууны мал аж ахуй эрхэлдэг нийт хүн амын 80\% хамрагджээ. ${ }^{4}$ Нүүлгэсний дараа малчдын амьдралын түвшин урьдынхаасаа доор болсон байдал гарсан байв. Малчдын хөдөлмөрлөх цаг болон хөдөлмөрлөх эрчим бүр нэмэгдсэн боловч орлого нь харин буурчээ. Зарим нь бүр орлогогүй болж, ядуурал нүүрлэсэн байна. "малчдыг зогсоож, бэлчээрийг сэргээх инженерчлэлийн” нэрээр эдгээр малчдад тогтсон хугацаанд нөхвөр мөнгө олгосон боловч малчдын орлогын асуудлыг үндсээр нь шийдвэрлэж чадсангүй.

2. Хөлөнбуйр хотод эрчим хүч, уул уурхай төвлөрч байгаа газар оронд нээн ашиглах явцад бүр уурхайн ойр хавиар газар цөмөрсөн байдал гарч байлаа. Газар цөмөрсөн буюу газрын хөрс доошоо сууж шилжсэн нийт талбай нь 6239.05 га-д хүрч, түүний дотор Залайнуур уурхайн бүсэд 2090 га, Боршил уурхайн бүсэд 400.30 га, Даян уурхайн бүсэд 2744.75 га, Имин уурхайн бүсэд 404 га хүрч, нийт эвдрэл хохирол гарсан газрын талбайн 43.45\%, 6.4\%, 43.56\%, 6.5\% хувийг тус тус эзэлжээ. ${ }^{5}$ Түүний гол шалтгаан бол эрчим хүч болон уул уурхайн төвлөрсөн нээн ашиглалтын бүсийн газрын доорх усны системд нөлөөлж, эвдрэл учирсан, далд усны давхаргын бүтэц эвдэрсэн, уурхай малтах явцад газар доорх усны түвшин доошилсон

4 Хун Хуа /红花/ “Хөдөө оронд уул уурхай малтах явцад тулгамдсан экологийн асуудал”/草原牧区工矿开发当中面临的生态环境问题/ [J], Эрчим хүчийг арвилан гамнах болон хүрээлэн буй орчин, 2013(2).

5 Сюй Руй /许荵/ “Хөлөнбуйрын эрчим хүч, уурхай нээн ашиглалтын явцад газар зүйн орчны шинжилгээ” /呼伦贝尔能源矿产资源中开采区矿山地质环境调查与研 究/, [D] Хятадын Газар Шинжилгээний Их Сургууль, 2014. 
зэргээс болжээ.

3. Шилийн гол аймгийн Сөнөд Зүүн хошуунд уул уурхайн нээн ашиглалтыг хэрэгжүүлсэнээр нэг талаар тус хошууны эдийн засгийн өсөлтийг бий болгосон боловч нөгөө талаар тухайн орны байгаль экологийн орчинд туйлын хүнд эвдэрлийг авчирсан байна. Олонхи аж ахуй, компани өөрийн өртгөө бууруулах зорилгоор задгай уурхай ашигласнаар газрын хөрсний давхаргыг эвдэж, ургамлын бүрхэвчийг сүйтгэв. Ухаж гаргасан уурхайн шороог овоолсоноор их хэмжээний бэлчээр нутгийг эзэлж, уулын байгалийн экологийн системийг эвдэлжээ. Судалгааны зарим үр дүнгээс үзэхүл, тус хошууны газар доорх усан дахварга нь тун гүехэн байж, ерийн гүний хэмжээ 1.5-2.0 метр, нэг өдөрт нэг худгаас гарах усны хэмжээ 20 тонн байв. ${ }^{6}$ Үүнээс гадна, уурхай малтах явцад бий болсон их хэмжээний хаягдал бохир ус гадаргын дээрх ус, хөрс шороо болон усны эх сурвалжийг ноцтой бохирдуулжээ. Хүчиллэг чанартай, хортой, хүнд төмөрлөг агуулсан бохирдол, хүнд элементүүд голын урсгал, агаарын тоосоор дамжин орчин тойрныг ихээр бохирдуулав.

\section{Дүгнэлт}

Аж үйлдвэржилтийг хэрэгжүүлэхэд заавал түүнд зохицсон байгаль орчны нөхцөл хийгээд дэвшилтэт технологийн мэргэжлээр хангагдсан байх ёстой. Монголын Өндөрлөгийн эх байгаль ган хуурай цаг агаарын нөхцөлтэй, усны нөөц харьцангуй дутмаг, экологи орчны нөхцөл тун сөрөг байдаг. Сохор балайгаар эдийн засгийн өсөлтийг хөөцөлдөж, уул уурхай ихээр нээн ашиглах, хот суурин ихээр тэлж хөгжүүлэх, их хэмжээгээр атар хагалбарлаж газар тариалан эрхлэх зэрэг нь усны нөөц баялаг дутмаг байдаг Монголын Өндөрлөгийн байгалийн нөхцөл байдлаас шалтгаалж гарцаагүй ялагдалд учрахаар үл барам, цаашдаа бас хүнд ноцтой гамшгийн үр дагаврыг авчрах магадлалтай гэдгийг тус өгүүлэлд дурдсан тодорхой жишээ баримтаас ойлгож болно.

6 Шан Янан /尚雅楠/ “Тал нутгийн уурхайн баялгийг нээх явцад экологийн орчны нөхвөр мөнгө олгох асуудал” /草原矿产资源开发的生态补偿问题研究/ [D], Өвөр Монголын Багшийн Их Сургууль, 2010. 
Аж үйлдвэржилт болон тал нутгийн усны эх сурвалж дутагдах нөхцөл байдал хийгээд түүний үр дагавар

Монголын Өндөрлөг бол нүүдэлчдийн түүхт эх орон болно. Монголчууд нүүдлийн мал аж ахуй эрхэлсэн урт удаан амьдралын түүх бол нэг ёсондоо байгаль орчны хатуу нөхцөл, хуурай цаг агаар, усны нөөц ховор байдаг ахуй байдалтай нягт шүтэлцэн гарч ирсэн билээ. Монголын нүүдлийн соёл иргэншил бол хүн төрөлхтөний нандин өв билээ. Монголын Өндөрлөгийн дархан байгаль, бэлчээрийн мал аж ахуй бол монгол нүүдэл, урт удаан түүхэн цаг хугацааны явцад байгалийн хатуу шалгалт, хүний нийгмийн хувьсал шилжилтийн сорилтоор дамжин нотлогдсон нэгэн төрлийн сонгодог эдийн засгийн хэлбэр болно.

\section{Ном зүй:}

1. Зэн Жянхун /甄江红/ “Өвөр Монгольн Хөххот, Бугат, Ордос хотын аж үйлдвэржилт болон экологийн хамгаалалтын судалгаa”/内蒙古呼包鄂地区工业化与生态文明建设研究/ [M], Хятадын Хөдөө Аж Ахуйн Хэвлэлийн Хороо, 2015.

2. Сун Цайжи/孙才志/ “Усны ядуулаг байдал доорх Хятадын хөдөө дэх усны нөөцийг нэмэгдүүлэхэд туслалцаа үзүүлэх бодлогын тухай судалгаа"/水贫困背景下中国农村水资源援助战略研究/ [J], Усны ашиглалтын эдийн засаг, 2015 (33).

3. Хун Хуа /红花/ “Хөдөө оронд уул уурхай малтах явцад тулгамдсан экологийн асуудал”/草原牧区工矿开发当中面临的生 态环境问题/[J], Эрчим хүчийг арвилан гамнах болон хүрээлэн буй орчин, 2013(2).

4. Сюй Руй/许荵/ “Хөлөнбуйрын эрчим хүч, уурхай нээн ашиглалтын явиад газар зүйн орчны шинжилгээ”/呼伦贝尔能源 矿产资源中开采区矿山地质环境调查与研究/, [D] Хятадын Газар Шинжилгээний Их Сургууль, 2014.

5. Шан Янань/尚雅楠/ “Тал нутгийн уурхайн баялгийг нээх явцад экологийн орчны нөхвөр мөнгө олгох асуудал”/草原矿产资源 开发的生态补偿问题研究/ [D], Өвөр Монголын Багшийн Их Сургууль, 2010. 


\section{ANALYSIS OF INDUSTRIALIZATION, CONDITION OF WATER SHORTAGE IN GRASSLAND AND ITS IMPACTS}

M.Burenjargal

In the process of Industrialization, the development of industry and urban constrction in the pastoral areas of Inner Mongolia has achieved rapid economic growth and development. However, due to the lack of objective conditions of water recources, the grassland has brought serious ecological and environmental problems.The Mongolian plateau nomadic grassland animal husbandry has a long development history. It is a classic economic way that to experince the challenge of nature and the change of human society. In the period of industrialization, the people should be cotinue to adhere and develop grassland animal husbandry economy in mongolia plateau, which is rational choice to adopt to the natural environmant .

Keywords: Industridlazation, Water Resources, Mongolia Plateau, Grassland Animal Husbandry 